\title{
The extract from Agkistrodon halys venom protects against lipopolysaccharide (LPS)- induced myocardial injury
}

\author{
Quan-Hai Wang ${ }^{1 \dagger}$, Wei Li ${ }^{2 \dagger}$, Yu-Xin Jiang ${ }^{3}$, Xiao-Hua Lu ${ }^{2}$ and Guo-Guang Wang ${ }^{2^{*}}$ (D)
}

\begin{abstract}
Background: Snake venoms contain various bioactive constituents which possess potential therapeutic effects. The aim of this work was to investigate the effect of the extract from Agkistrodon halys venom on lipopolysaccharide (LPS)-induced myocardial injury.

Methods: Thirty male Sprague-Dawley rats were randomly assigned to three groups (10 rats per group): control group, LPS group and LPS + extract group. Rats in control and the LPS groups were intravenously injected with sterile saline solution, and rats in the LPS + extract group with the extract. After $2 \mathrm{~h}$, rats of the control group were intraperitoneally injected sterile saline solution, and rats in the LPS and the LPS + extract groups were treated with LPS (20 mg per kg body weight). Levels of creatine kinase (CK) and lactate dehydrogenase (LDH) in serum were determined. Anti-inflammation of the extract was analyzed via determination of TNF-a and IL-6 in serum, and expression of TNF-a, IL-6, COX-2 and p-ERK protein in hearts. Heme oxygenase-1 (HO-1) and p-NF-KB protein expression in hearts, superoxide dismutase (SOD) activity and malondialdehyde (MDA) level in serum were used to evaluate the anti-oxidative properties of the extract.
\end{abstract}

Results: Extract pretreatment significantly decreased the level of serum $\mathrm{CK}$ and $\mathrm{LDH}$, reduced the generation of inflammatory cytokines such as TNF- $a$ and IL-6, and also reduced serum level of MDA in the LPS + extract group compared with the LPS group. In addition, the extract increased SOD activity in serum, HO-1 protein expression in hearts, and decreased TNF-a, IL-6, COX-2, p-NF-KB and p-ERK1/2 protein expression.

Conclusion: Our results suggested that beneficial effect of this extract might be associated with an improved anti-oxidation and anti-inflammatory effect via downregulation of NF-kB/COX-2 signaling by activating HO-1/ $\mathrm{CO}$ in hearts.

Keywords: Agkistrodon halys venom, LPS, Myocardial injury

\section{Background}

Acute myocardial infarction, same as sepsis, is a major cause of high mortality [1]. Lipopolysaccharide (LPS), a bacterial endotoxin located in the outer membrane of the cell wall of the Gram-negative bacteria, is considered as the principal factor responsible for multiple organs damage including myocardial injury in patients with sepsis $[2,3]$. Indeed, various evidences show that myocardial injury is the principal contributor to mortality in

\footnotetext{
* Correspondence: guoguangw1226@sina.com

${ }^{+}$Quan-Hai Wang and Wei Li contributed equally to this work.

2Department of Pathophysiology, Wannan Medical College, 22 West

Wenchang Road, Yijiang District, Wuhu 241002, China

Full list of author information is available at the end of the article
}

septic patients $[4,5]$. LPS results in the overexpression and release of proinflammatory cytokines, including tumor necrosis factor- $\alpha$ (TNF- $\alpha)$, interleukin-1 $\beta$ (IL-1 $\beta)$, and interleukin-6 (IL-6), which contribute to LPSinduced multiple organs failure including myocardial depression [6, 7]. Furthermore, LPS activates nuclear factor$\mathrm{\kappa B}(\mathrm{NF}-\mathrm{\kappa B})$ and mitogen-activated protein kinase (MAPK) pathways via recognizing Toll-like receptors (TLR), which upregulate the expression of cyclooxygenase-2 (COX-2), subsequently promoting the synthesis and release of inflammatory cytokines $[8,9]$. In addition, LPS increases reactive oxygen species (ROS) generation, oxidative stress and activation of stress signaling including mitogen-

(c) The Author(s). 2019 Open Access This article is distributed under the terms of the Creative Commons Attribution 4.0 International License (http://creativecommons.org/licenses/by/4.0/), which permits unrestricted use, distribution, and reproduction in any medium, provided you give appropriate credit to the original author(s) and the source, provide a link to the Creative Commons license, and indicate if changes were made. The Creative Commons Public Domain Dedication waiver (http://creativecommons.org/publicdomain/zero/1.0/) applies to the data made available in this article, unless otherwise stated. 
activated protein kinase (MAPK), which promote apoptosis of cardiac myocytes and myocardial dysfunction in sepsis [10, 11]. LPS is a crucial factor generating multi-organ failure in sepsis, including cardiac failure confirmed by experimental and clinical studies [12-14]. Accordingly, inhibition of proinflammatory cytokines is beneficial to reduce septic shock $[15,16]$, and antioxidants attenuate LPSinduced myocardial depression $[17,18]$.

Snake bite is dangerous to public health due to its hemotoxic, neurotoxic, and cardiotoxic effects, which can result in death. However, snake venoms contain various bioactive constituents which possess potential therapeutic effects [19]. Snake venoms are complex mixtures composed of proteins, polypeptides and nonprotein components such as metalloproteases and phospholipase A2 [20]. Many researchers pay great attention to the medical value of snake venom components. Many progresses have been made in the use of snake venom constituents to develop medications including anti-hypertensive and anti-stroke drugs, and some studies suggested that venom extracts possess anti-cancer activity [21, 22]. Several proteins separated from snake venoms affect blood circulation and coagulation, for example, the extract from Agkistrodon contortrix venom can activate protein C (PC) [23, 24]. Activated PC (APC) results from the circulating PC cleaved by thrombin and it plays a vital role in coagulation homeostasis. Furthermore, APC increases the survival of patients with sepsis through its antiinflammatory effect [25] by reducing both NF- $\mathrm{kB}$ pathway and expression of pro-inflammatory cytokines such as TNF- $\alpha$ and IL- 6 induced by LPS $[26,27]$. Thus, PC activator (PCA) might increase the anti-inflammatory effect. Recently, we isolated a component with enzymatic activity from Agkistrodon halys' venom. An experimental study indicated that it can activate PC. We also investigated the functions of the extract, and the results showed that it improves cardiac hemodynamics in septic shock rats. Furthermore, according to the literature, this extract alleviates diabetic cardiomyopathy, and increases antiinflammation in STZ-induced diabetic rats [28]. In addition, we also separated other components with bioactivity from snake venoms. Preliminary studies suggested that some peptides displayed analgesia, and the protein could attenuate cerebral ischemia/reperfusion injury, but these components need further identification. In this study, we hypothesize that PCA from snake venom attenuates LPS-induced myocardial injury on the basis of previous results. Therefore, in the present work the effect of the extract on myocardial injury in sepsis induced by LPS was further analyzed, together with its anti-inflammatory and antioxidative effects.

\section{Methods \\ Materials}

Lipopolysaccharide (LPS, Escherichia coli 0111:B4) was purchased from Sigma (St. Louis, USA). ELISA rat IL-6 and TNF- $\alpha$ kits were purchased from Hefei Bomei Biotechnology CO., LTD (Hefei China). Primary polyclonal antibodies $\beta$-actin, HO-1, COX-2, NF- $\mathrm{kB}, \mathrm{p}-\mathrm{NF}-\mathrm{Kb}$, pERK1/2, ERK were purchased from Bio Basic Inc., Canada.

\section{Animals}

Male Sprague-Dawley rats (260-300 g) were provided by the Experimental Animal Center in Wannan Medical College (Wuhu, China) and raised in the animal house facilities of the Experimental Center for Function Subjects at Wannan Medical College under a 12-h day/light cycle and controlled temperature of $22^{\circ} \mathrm{C}$. Rats were fed with a standard pellet diet and they had access to water ad libitum. This project was approved by the Academic Experimental Animal Care and Use Committee of Wannan Medical College.

\section{Extract of Agkistrodon halys venom}

The extract from Agkistrodon halys venom was supplied by the Snake Venom Research Institute, Wannan Medical College. The extract used in the study displays high similarity with acurhagin precursor with activity of metalloproteinase. The lyophilized extract was stored at $20^{\circ} \mathrm{C}$. Extract solution $(1 \mathrm{mg} / \mathrm{ml})$ was prepared in sterile saline solution. Number: 20130041502.

\section{Induction of myocardial injury}

A total of thirty male Sprague-Dawley rats were used in this work. After acclimatization for 1 week, rats were randomly assigned to three groups (10 rats per group): control group, LPS group and LPS + extract group. Rats were anesthetized by an intraperitoneal injection of sodium pentobarbital ( $40 \mathrm{mg} / \mathrm{kg}$, i.p.) (Sigma, St. Louis, USA). Rats of the control and LPS groups were intravenously treated with sterile saline solution, and rats of the LPS + extract with the extract from snake venom $(100 \mu \mathrm{g} / \mathrm{kg})$. Myocardial injury was induced as described previously [9]. Briefly, after $2 \mathrm{~h}$ of injection with the extract, rats from the LPS and LPS + extract groups were intraperitoneally injected with LPS ( $20 \mathrm{mg}$ per $\mathrm{kg}$ body weight, dissolved in sterile saline) (Sigma, St. Louis, USA) for cardiomyopathy induction, while the control group were treated again with sterile saline solution (intraperitoneally) as control. After $6 \mathrm{~h}$ of LPS administration, the carotid artery of rat was seperated and cannulated for collection of blood sample. Further, animals were anaesthetised via bleeding. Blood samples were collected for biochemical analysis. Hearts were removed for each group, and six of them were stored 
at $-70{ }^{\circ} \mathrm{C}$ until use and the other four were fixed in $4 \%$ neutral formalin for histological analysis. At the end of experiment, rats' survival rate was $10 / 10$ in each group.

\section{Biochemical analysis}

Blood samples were centrifuged to obtain the serum. Serum levels of creatine kinase (CK) and lactate dehydrogenase (LDH) were determined by an automated biochemical analyzer.

\section{Analysis of antioxidation}

To evaluate effect of the extract on the antioxidation in the serum, superoxide dismutase (SOD) activity was measured by the xanthine oxidase method, and malondialdehyde (MDA) content was determined by the thiobarbituricacid method using diagnostic kits (Nanjing Jiancheng Bioengineering Institute, Nanjing, China) according to the manufacturer's protocol. Serum diluted with $10 \mathrm{mmol} / \mathrm{L} \mathrm{NH}_{2} \mathrm{OH} \cdot \mathrm{HCl}, 7.5 \mathrm{mmol} / \mathrm{L}$ xanthine and $0.2 \mathrm{mg} / \mathrm{ml}$ xanthine oxidase was incubated at $37^{\circ} \mathrm{C}$ for $30 \mathrm{~min}$, and then was mixed with chromogenic agent for $10 \mathrm{~min}$. Absorbance at $530 \mathrm{~nm}$ was determined for measurement of SOD activity. Mixture of serum with $0.6 \%$ thiobarbituricacid $(1: 1, \mathrm{v} / \mathrm{v})$ was boiled for $15 \mathrm{~min}$, and then centrifuged for $10 \mathrm{~min}$. MDA content was measured by determining absorbance at 532 and $450 \mathrm{~nm}$.

\section{Determination of TNF- $a$ and IL- 6}

TNF- $\alpha$, and IL- 6 contents in serum were evaluated using TNF- $\alpha$, and IL- 6 specific ELISA kits (Hefei Bomei Biotechnology CO., LTD, China) according to the manufacturer's instructions.

\section{Morphometric analysis}

Hearts fixed in $4 \%$ neutral formalin were embedded in paraffin after dehydration, and cut into $5-\mu \mathrm{m}$ sections used for hematoxylin-eosin staining. Stained sections were observed under a light microscope for histomorphological analysis.

\section{Western blot}

Hearts stored at $-70{ }^{\circ} \mathrm{C}$ were lysed and homogenized inice-cold lysis buffer $(50 \mathrm{mmol} / \mathrm{L}$ HEPES, $100 \mathrm{mmol} / \mathrm{L}$ sodium pyrophosphate, $10 \mathrm{mmol} / \mathrm{L}$ sodium orthovanadate, $100 \mathrm{mmol} / \mathrm{L}$ sodium fluoride, $10 \mathrm{mmol} / \mathrm{L}$ EDTA, and $1 \%$ Triton X-100) containing $2 \mathrm{mmol} / \mathrm{L}$ phenylmethyl sulfonyl fluoride. Homogenates were centrifuged at $12,000 \mathrm{~g}$ for $20 \mathrm{~min}$ at $4{ }^{\circ} \mathrm{C}$. Equal amounts of denatured protein in supernatants were separated by electrophoresis on 12\% SDS-PAGE and then transferred onto nitrocellulose membranes. The membranes were incubated with rabbit anti-rat primary antibodies such as $\beta$ actin, HO-1, COX-2, NF- $k B$, p-NF- $k B$, p-ERK1/2, ERK,
(Bio Basic Inc., Canada) overnight at $4{ }^{\circ} \mathrm{C}$. Subsequently, membranes were incubated with a horseradish peroxidaseconjugated secondary goat anti-rabbit antibody. After rinsing, proteins were visualized by DAB staining (Bio Basic Inc., Canada).

\section{Statistical analysis}

Statistical analysis was performed using SPSS16.0 (IBM Corp., Armonk, NY, USA). Tukey's test for unpaired data and one-way Analysis of Variance (ANOVA) were used to determine statistical differences, followed by Bonferroni's post-test. All values were expressed as mean $\pm \mathrm{SD}$. A $p$ value $<0.05$ was considered statistically significant.

\section{Results}

\section{Effect of the extract on CK and LDH}

The extract used in the study was a component which we recently isolated from Agkistrodon halys venom. The extract has been identified, and its function has been reported in previous study [28].

To evaluate effect of the extract on LPS-induced myocardial injury, CK and LDH serum levels were determined. As shown Fig. 1, CK and LDH levels were significantly increased in LPS group when compared to the control $(p<0.01)$, while the extract treatment markedly reduced their levels in the LPS + extract group compared to the LPS group $(p<0.01)$.

\section{Change of antioxidation}

LPS treatment significantly reduced SOD activity, and increased the content of MDA in serum from rats of the LPS group compared with the control group $(p<0.01)$ (Fig. 2). Extract administration enhanced SOD activity, and decreased MDA content when compared to the LPS + extract group $(p<0.01)$ (Fig. 2).

Furthermore, HO-1 expression was detected in myocardium. The data showed that its expression was decreased in the LPS group compared with the control group $(p<0.01)$ (Fig. 2$)$, while the extract significantly increased HO-1 expression in LPS + extract group when compared to the LPS group $(p<0.01)$ (Fig. 2$)$.

\section{Anti-inflammatory effect of the extract}

Levels of TNF- $\alpha$ and IL- 6 in serum were significantly increased in the LPS group compared with the control group $(p<0.01)$ (Fig. 3). Treatment with extract prior to LPS markedly decreased TNF- $\alpha$ and IL- 6 levels compared to the LPS group $(p<0.01)$ (Fig. 3).

In addition, LPS treatment significantly increased TNF- $\alpha$ and IL- 6 levels in the heart of rats from LPS group compared with the control group $(p<0.01)$ (Fig. 3), while they were reduced in LPS + extract group $(p<0.01)$ (Fig. 3). 

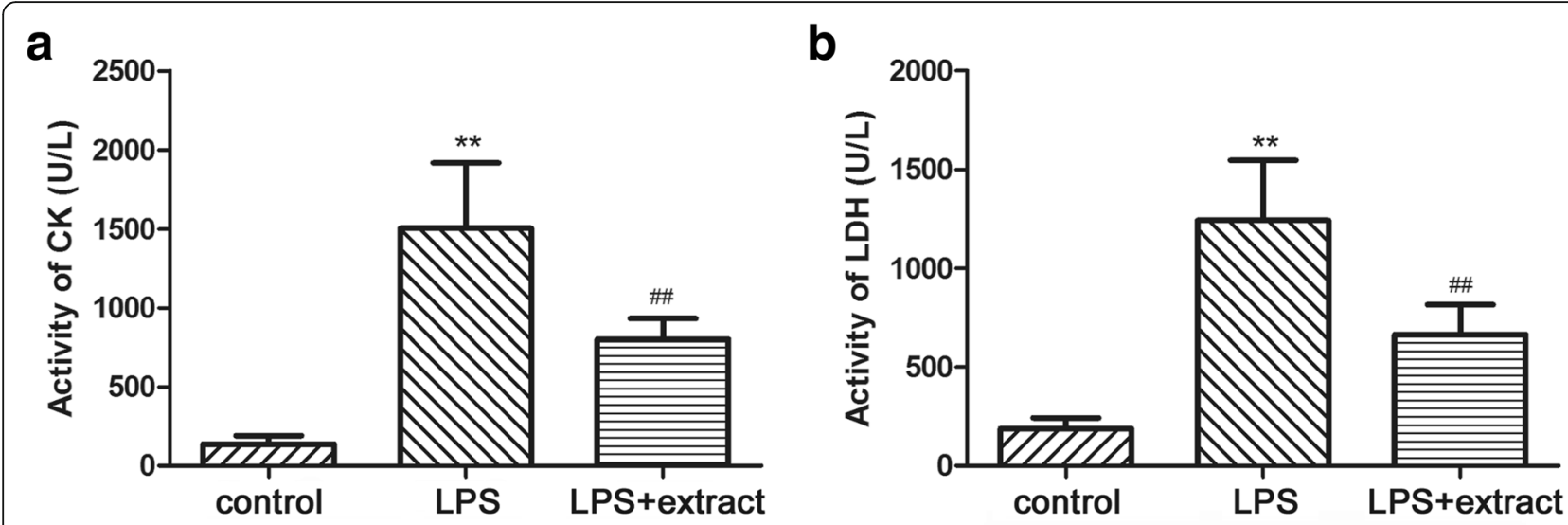

Fig. 1 Effect of venom extract on CK and LDH in rat serum. Activity of CK (a) and LDH (b) was determined by automated biochemical analyzer. The results were expressed as $U / L$ in serum. Values were expressed as means $\pm S D$. ${ }^{* *} p<0.01$ vs. Control group; ${ }^{\# \#} p<0.01$ vs. LPS group ( $n=10$ )

\section{Morphometric change}

Histological observation showed that inflammatory cell infiltration was increased in the hearts of the LPS group compared with the ones from the control group. Myofibrillar fragmentation and cardiacmyocytes swelling were found in the LPS group (Fig. 4). Treatment with the extract reduced both these effects induced by LPS (Fig. 4).

\section{COX-2, p-ERK1/2, and p-NF-KB protein expression}

$\mathrm{p}-\mathrm{NF}-\mathrm{kB}, \mathrm{COX}-2$, and $\mathrm{p}-\mathrm{ERK}$ protein expression was measured to evaluate inflammation. As shown in Fig. 5, exposure to LPS increased the expression of NF- $\mathrm{kB}$, COX-2, and p-ERK proteins in heart from in the LPS group when compared to the control group. Pretreatment with the extract reduced the expression of all the mentioned proteins.

\section{Discussion}

In the present study, we explored the protective effect of the extract from Agkistrodon halys venom on LPSinduced myocardial injury. Our results showed that this extract significantly decreased plasma $\mathrm{CK}$ and $\mathrm{LDH}$

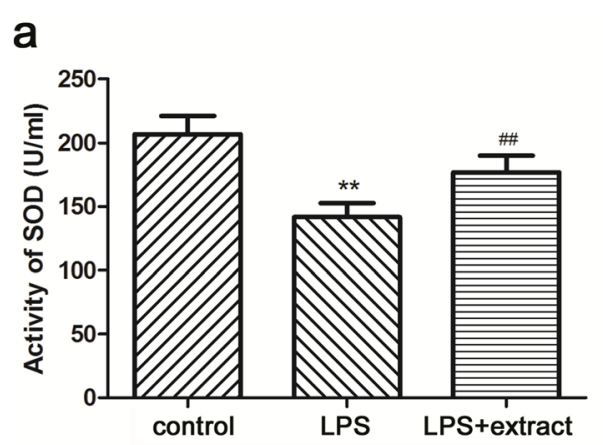

b

C
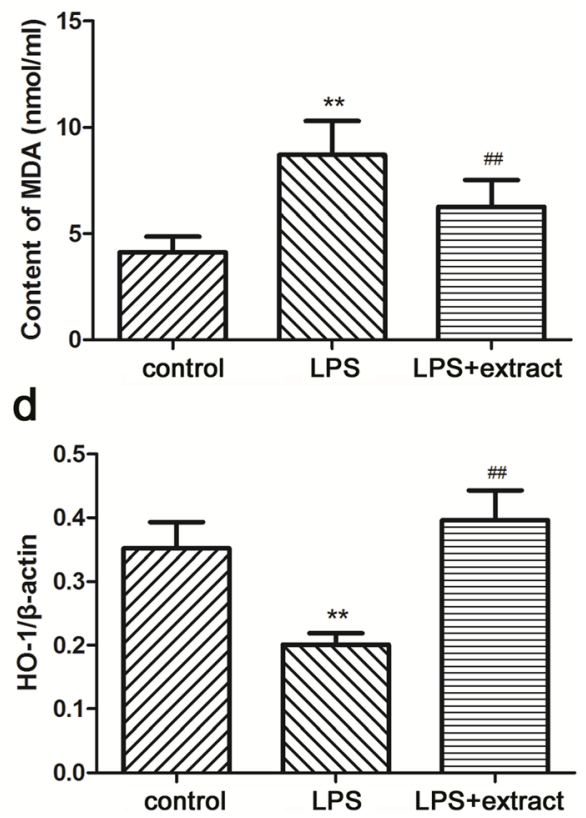

Fig. 2 Effect of the venom extract on antioxidants. Serum SOD activity (a) and MDA content (b) were measured. The results were expressed as means \pm SD $(n=10)$. HO-1 expression in hearts was analyzed by western blot (c). Relative amount of HO-1 was assessed by HO-1 to $\beta$-actin ratio (d) $(n=6) .{ }^{* *} p<0.01$ vs. Control group; ${ }^{\# \#} p<0.01$ vs. LPS group 
a

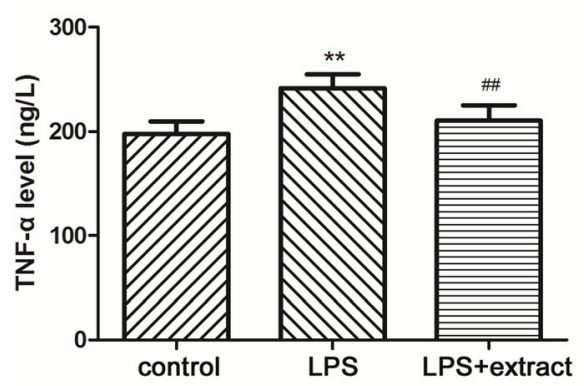

C

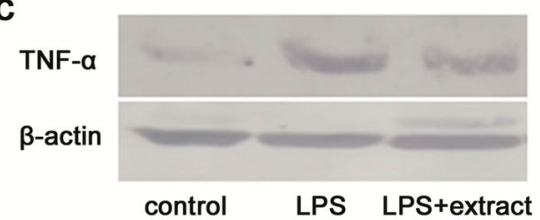

d

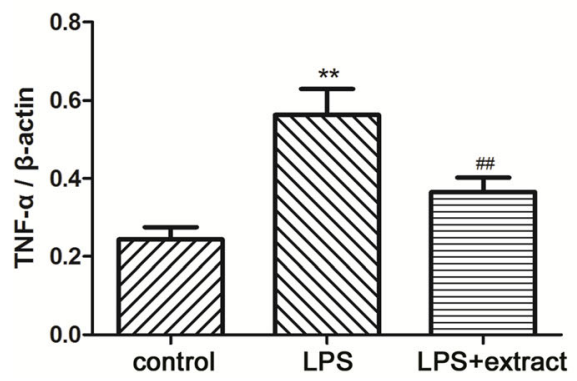

b

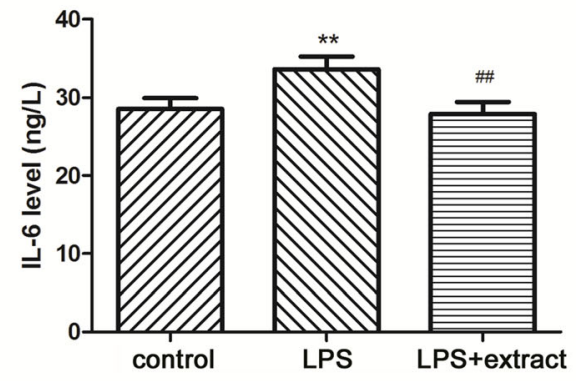

e

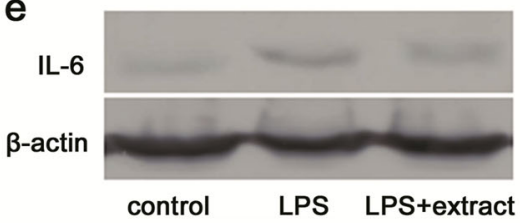

f

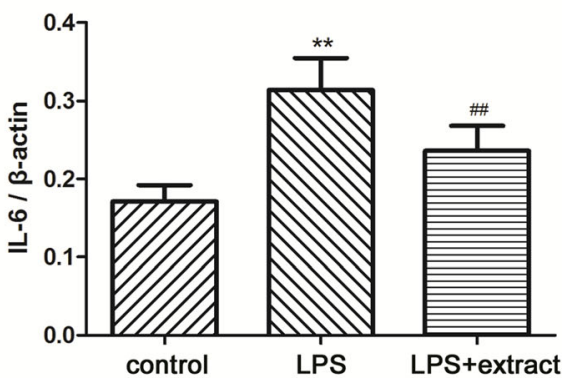

Fig. 3 Effect of the venom extract on inflammation. Seruml evels of TNF-a (a) and IL-6 (b) were determined by TNF-a, and IL-6 specific ELISA kit. Values were expressed as means \pm SD $(n=10)$. TNF- $a(\mathbf{c})$ and IL-6 (e) in hearts were analyzed by western blot. Relative amounts of TNF-a (d) and IL-6 (f) were assessed by TNF- $a$ and IL-6 to $\beta$-actin ratio $(n=6)$, respectively. ${ }^{* *} p<0.01$ vs. Control group; ${ }^{\# \#} p<0.01$ vs. LPS group

level, lowered the serum level of pro-inflammatory cytokines such as TNF- $\alpha$ and IL-6, and the content of lipid peroxidation product such as MDA. Pretreatment with the extract also enhanced serum SOD activity, increased HO-1 expression, but reduced $\mathrm{p}-\mathrm{NF}-\mathrm{kB}, \mathrm{COX}-2$, and p-ERK expression in rat hearts. These results suggest that this extract was beneficial to LPS-induced myocardial injury.
Oxidative stress and inflammatory response play an important role in acute and chronic myocardial injury [29]. Inflammatory cytokines such as TNF- $\alpha$ and IL-6 result in cardiac dysfunction in sepsis [30]. LPS dramatically stimulates the release of inflammatory cytokines including TNF- $\alpha$ via binding to toll-like receptor-4 (TLR-4) [31]. Clinical and experimental studies indicated that cardiac dysfunction is closely associated with the

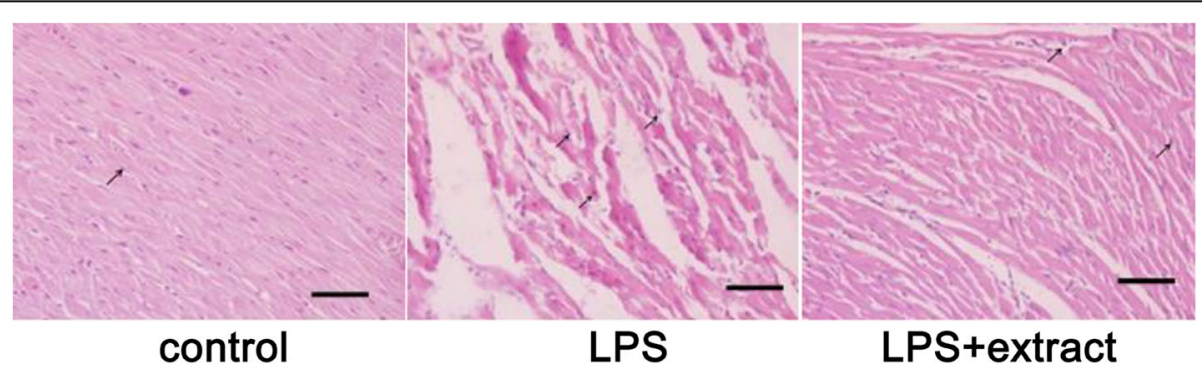

Fig. 4 Morphometric change. Heart samples were collected $6 \mathrm{~h}$ after injection with LPS, fixed in formalin, and sections were cut and stained with hematoxylin-eosin. Scale bar: $50 \mu \mathrm{m} .400 \times$ magnification 


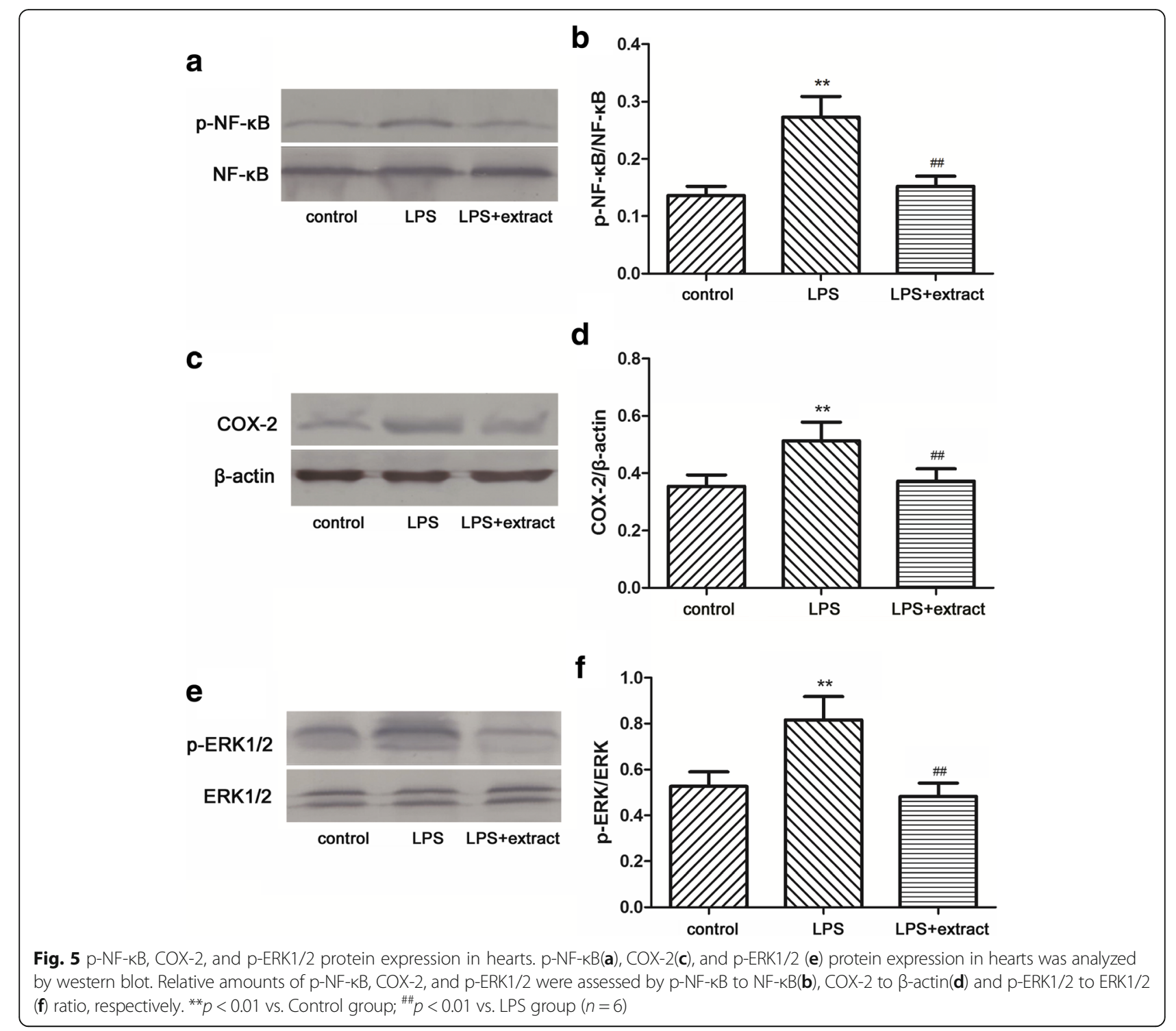

release of inflammatory cytokines in sepsis [12, 32], and cardiac function can be improved via decreasing TNF- $\alpha$ level in septic animal model and patients with sepsis $[33,34]$. Oxidative stress results in excessive generation of ROS and MDA, and reduces activity of antioxidative enzymes such as SOD, and HO-1 protein expression [35]. Excessive ROS caused damage to cells and various tissues through impairing macromolecules such as protein and DNA, and mitochondrial function [36]. Accumulating evidence shows that inflammation provokes oxidative stress, and oxidative stress enhances inflammation [37]. APC decreases the level of LPS-induced pro-inflammatory cytokines in sepsis [27]. In the present study, the extract from Agkistrodon halys venom, an activator of protein C, was used to pretreat rats before LPS injection. The results showed that the extract decreased the level of inflammatory cytokines such as TNF- $\alpha$ and IL-6 levels, and MDA content in serum. The extract also increased SOD activity.

A previous study showed that the extract can activate PC [28]. APC has been reported to possess antiinflammation and anti-apoptotic effect [38]. Thus, we preliminarily investigated the effect of the extract on inflammation. LPS can upregulate mitogen-activated protein kinase (MAPK)/extracellular signal-regulated kinase (ERK), and enhance inflammatory response [39, 40]. Furthermore, reduction of ERK activation attenuates cardiac fibrosis [41]. In addition, LPS binding to TLR4 results in inflammation, which is associated with NK- $\mathrm{KB}$ activation [42]. Phosphorylation of NK-kB results in the release of NK- $\kappa B$ bound to the inhibitor IкB $[43,44]$. Dimerized NK$\kappa B$ moves to nucleus, and stimulates the expression of genes associated with inflammation including inflammatory 
cytokines, and COX-2 [45]. Furthermore, ERK1/2 and MAPK are also implicated in the regulation of inflammatory cytokines and COX-2 [46, 47]. In our study, the results suggested that the extract reduced inflammatory cytokines, COX-2 protein expression, and activation of ERK1/2, NK$\kappa B$ and MAPK. Therefore, the protective effect of the extract might be associated with its anti-inflammatory effect.

In this study, pretreatment with the extract increased $\mathrm{HO}-1$ expression in the heart. $\mathrm{HO}-1$, an endogenous antioxidant, alleviates oxidative stress, and protects cells and tissues from the effect of oxidative stress $[48,49]$. HO-1 can convert heme into carbon monoxide (CO), biliverdin, and free iron. Various studies showed that the conversion products such as biliverdin and $\mathrm{CO}$ possess antioxidative effects $[50,51]$. CO, a catalytic product of HO-1, is associated with diverse physiological action [52]. CO, regarded as a gas signal molecule, exerts antioxidative, anti-inflammatory and anti-apoptotic effects [53]. Previous studies suggested that $\mathrm{HO} / \mathrm{CO}$ pathway is involved in mediation of inflammation and cytoprotection $[54,55]$. This study indicated that HO-1 could reduce the production of inflammatory cytokines, the expression of COX-2, and MDA generation [56].

\section{Conclusions}

In conclusion, our study showed that the extract from Agkistrodon halys venom alleviated LPS-induced myocardial injury. Its beneficial effect might be associated with its effect on improvement of antioxidation and reduction of inflammation by increasing $\mathrm{HO}-1$ expression, and downregulating $\mathrm{p}-\mathrm{NF}-\mathrm{kB} / \mathrm{COX}-2$ signaling in hearts.

\begin{abstract}
Abbreviations
CK: Creatine kinase; CO: Carbon monoxide; COX-2: Cyclooxygenase-2; ERK: Extracellular signal-regulated kinase; HO-1: Heme Oxygenase-1; IL6: Interleukin-6; LDH: Lactate dehydrogenase; LPS: Lipopolysaccharide; MAPK: Mitogen-activated protein kinase; MDA: Malondialdehyde; NF-kB: Nuclear factor kappa B; PCA: Protein C activator; ROS: Reactive oxygen species; SOD: Superoxide dismutase; TLR: Toll-like receptors; TNF-a: Tumor necrosis factor-a
\end{abstract}

\section{Acknowledgements}

We thank the Experimental Center for Function Subjects for their substantial facilitations of all necessary materials and equipment.

\section{Authors' contributions \\ QHW and WL carried out the molecular experiments, and XHL performed the tissue experiments. WL performed the statistical analysis. GGW and YXJ conceived the experiments, and participated in its design and helped to draft the manuscript. All authors participated in data interpretation and review of the manuscript, and approved the final manuscript.}

\section{Funding}

This study was supported by the University Natural Science Foundation of Anhui Province (number: KJ2017ZD20), the National Natural Science Foundation of China (number: 81172790), and initial funding of Wannan Medical College (number: 06020204).

\section{Availability of data and materials}

The datasets used and analysed during the current study are available from the corresponding author on reasonable request.

\section{Ethics approval}

All animal experiments in this study was approved by the Animal Ethical Care and Use Committee of Wannan Medical College.

\section{Consent for publication}

Not applicable.

\section{Competing interests}

All the authors declare that they have no competing interests.

\section{Author details}

'Department of Histology and Embryology, Wannan Medical College, Wuhu 241002, People's Republic of China. ${ }^{2}$ Department of Pathophysiology, Wannan Medical College, 22 West Wenchang Road, Yijiang District, Wuhu 241002, China. ${ }^{3}$ Department of Physiology, Wannan Medical College, Wuhu 241002, People's Republic of China.

Received: 22 March 2017 Accepted: 9 July 2019

Published online: 17 July 2019

\section{References}

1. Angus DC, Pereira CA, Silva E. Epidemiology of severe sepsis around the world. Endocrine, metabolic \& immune disorders drug targets. 2006;6(2): 207-12.

2. Venardos KM, Perkins A, Headrick J, Kaye DM. Myocardial ischemiareperfusion injury, antioxidant enzyme systems, and selenium: a review. Curr Med Chem. 2007;14(14):1539-49.

3. Angus DC, Wax RS. Epidemiology of sepsis: an update. Crit Care Med. 2001; 29(7 Suppl):S109-16

4. Fernandes C J Jr, de Assuncao MS. Myocardial dysfunction in sepsis: a large, unsolved puzzle. Critical care research and practice. 2012;2012:896430.

5. Merx MW, Weber C. Sepsis and the heart. Circulation. 2007;116(7):793-802.

6. Ward PA. The sepsis seesaw: seeking a heart salve. Nat Med. 2009;15(5):497-8.

7. Ren J, Wu S. A burning issue: do sepsis and systemic inflammatory response syndrome (SIRS) directly contribute to cardiac dysfunction? Frontiers in bioscience : a journal and virtual library. 2006;11:15-22.

8. Matsuno K, Iwata K, Matsumoto M, Katsuyama M, Cui W, Murata A, Nakamura H, Ibi M, Ikami K, Zhang J, et al. NOX1/NADPH oxidase is involved in endotoxininduced cardiomyocyte apoptosis. Free Radic Biol Med. 2012;53(9):1718-28.

9. Turdi S, Han X, Huff AF, Roe ND, Hu N, Gao F, Ren J. Cardiac-specific overexpression of catalase attenuates lipopolysaccharide-induced myocardial contractile dysfunction: role of autophagy. Free Radic Biol Med. 2012;53(6):1327-38.

10. Zhang WJ, Wei H, Frei B. Genetic deficiency of NADPH oxidase does not diminish, but rather enhances, LPS-induced acute inflammatory responses in vivo. Free Radic Biol Med. 2009:46(6):791-8.

11. Ben-Shaul V, Lomnitski L, Nyska A, Zurovsky Y, Bergman M, Grossman S. The effect of natural antioxidants, NAO and apocynin, on oxidative stress in the rat heart following LPS challenge. Toxicol Lett. 2001;123(1):1-10.

12. Liu CJ, Lo JF, Kuo CH, Chu CH, Chen LM, Tsai FJ, Tsai CH, Tzang BS, Kuo WW, Huang CY. Akt mediates 17beta-estradiol and/or estrogen receptoralpha inhibition of LPS-induced tumor necresis factor-alpha expression and myocardial cell apoptosis by suppressing the JNK1/2-NFkappaB pathway. J Cell Mol Med. 2009;13(9B):3655-67.

13. Baker L, Meldrum KK, Wang M, Sankula R, Vanam R, Raiesdana A, Tsai B, Hile K, Brown JW, Meldrum DR. The role of estrogen in cardiovascular disease. J Surg Res. 2003;115(2):325-44.

14. Opal SM, Scannon PJ, Vincent JL, White M, Carroll SF, Palardy JE, Parejo NA, Pribble JP, Lemke JH. Relationship between plasma levels of lipopolysaccharide (LPS) and LPS-binding protein in patients with severe sepsis and septic shock. J Infect Dis. 1999;180(5):1584-9.

15. Hall G, Singh IS, Hester L, Hasday JD, Rogers TB. Inhibitor-kappaB kinasebeta regulates LPS-induced TNF-alpha production in cardiac myocytes through modulation of NF-kappaB p65 subunit phosphorylation. Am J Phys Heart Circ Phys. 2005;289(5):H2103-11.

16. Haudek SB, Spencer E, Bryant DD, White DJ, Maass D, Horton JW, Chen ZJ, Giroir BP. Overexpression of cardiac I-kappaBalpha prevents endotoxininduced myocardial dysfunction. Am J Phys Heart Circ Phys. 2001;280(3): H962-8.

17. Ceylan-Isik AF, Zhao P, Zhang B, Xiao X, Su G, Ren J. Cardiac overexpression of metallothionein rescues cardiac contractile dysfunction and endoplasmic 
reticulum stress but not autophagy in sepsis. J Mol Cell Cardiol. 2010;48(2): 367-78.

18. Zhao P, Turdi S, Dong F, Xiao X, Su G, Zhu X, Scott Gl, Ren J. Cardiac specific overexpression of insulin-like growth factor I (IGF-1) rescues lipopolysaccharide-induced cardiac dysfunction and activation of stress signaling in murine cardiomyocytes. Shock. 2009;32(1):100-7.

19. Son DJ, Park MH, Chae SJ, Moon SO, Lee JW, Song HS, Moon DC, Kang SS, Kwon YE, Hong JT. Inhibitory effect of snake venom toxin from Vipera lebetina turanica on hormone-refractory human prostate cancer cell growth: induction of apoptosis through inactivation of nuclear factor kappaB. Mol Cancer Ther. 2007;6(2):675-83.

20. Leon G, Sanchez L, Hernandez A, Villalta M, Herrera M, Segura A, Estrada R, Gutierrez JM. Immune response towards snake venoms. Inflammation \& allergy drug targets. 2011;10(5):381-98.

21. Birrell GW, Earl ST, Wallis TP, Masci PP, de Jersey J, Gorman JJ, Lavin MF. The diversity of bioactive proteins in Australian snake venoms. Molecular \& cellular proteomics : MCP. 2007;6(6):973-86.

22. Park MH, Son DJ, Kwak DH, Song HS, Oh KW, Yoo HS, Lee YM, Song MJ, Hong JT. Snake venom toxin inhibits cell growth through induction of apoptosis in neuroblastoma cells. Arch Pharm Res. 2009;32(11):1545-54.

23. Lu Q, Clemetson JM, Clemetson KJ. Snake venoms and hemostasis. Journal of thrombosis and haemostasis : JTH. 2005;3(8):1791-9.

24. Markland FS. Snake venoms and the hemostatic system. Toxicon : official journal of the International Society on Toxinology. 1998;36(12):1749-800.

25. Esmon $\mathrm{CT}$. The interactions between inflammation and coagulation. $\mathrm{Br}$ J Haematol. 2005;131(4):417-30.

26. Yuksel M, Okajima K, Uchiba M, Horiuchi S, Okabe H. Activated protein C inhibits lipopolysaccharide-induced tumor necrosis factor-alpha production by inhibiting activation of both nuclear factor-kappa B and activator protein-1 in human monocytes. Thromb Haemost. 2002;88(2):267-73.

27. Okajima K. Regulation of inflammatory responses by natural anticoagulants. Immunol Rev. 2001:184:258-74.

28. Li S, Hong Y, Jin X, Zhang G, Hu Z, Nie L. A new Agkistrodon halys venompurified protein $\mathrm{C}$ activator prevents myocardial fibrosis in diabetic rats. Croat Med J. 2015;56(5):439-46

29. Grieve DJ, Byrne JA, Cave AC, Shah AM. Role of oxidative stress in cardiac remodelling after myocardial infarction. Heart, lung \& circulation. 2004;13(2): $132-8$.

30. Zhang T, Feng Q. Nitric oxide and calcium signaling regulate myocardial tumor necrosis factor-alpha expression and cardiac function in sepsis. Can J Physiol Pharmacol. 2010;88(2):92-104.

31. Meldrum DR. Tumor necrosis factor in the heart. Am J Phys. 1998:274(3 Pt 2):R577-95.

32. Kumar $V$, Sharma A. Is neuroimmunomodulation a future therapeutic approach for sepsis? Int Immunopharmacol. 2010;10(1):9-17.

33. Vincent JL, Bakker J, Marecaux G, Schandene L, Kahn RJ, Dupont E. Administration of anti-TNF antibody improves left ventricular function in septic shock patients. Results of a pilot study. Chest. 1992;101(3):810-5

34. Herbertson MJ, Werner HA, Goddard CM, Russell JA, Wheeler A, Coxon R, Walley KR. Anti-tumor necrosis factor-alpha prevents decreased ventricular contractility in endotoxemic pigs. Am J Respir Crit Care Med. 1995;152(2): 480-8.

35. Lowes DA, Webster NR, Murphy MP, Galley HF. Antioxidants that protect mitochondria reduce interleukin- 6 and oxidative stress, improve mitochondrial function, and reduce biochemical markers of organ dysfunction in a rat model of acute sepsis. Br J Anaesth. 2013;110(3):472-80.

36. Bian Q, Gao S, Zhou J, Qin J, Taylor A, Johnson EJ, Tang G, Sparrow JR, Gierhart D, Shang F. Lutein and zeaxanthin supplementation reduces photooxidative damage and modulates the expression of inflammationrelated genes in retinal pigment epithelial cells. Free Radic Biol Med. 2012; 53(6):1298-307.

37. Liu S, Feng G, Wang GL, Liu GJ. p38MAPK inhibition attenuates LPS-induced acute lung injury involvement of NF-kappaB pathway. Eur J Pharmacol. 2008:584(1):159-65.

38. Neyrinck AP, Liu KD, Howard JP, Matthay MA. Protective mechanisms of activated protein C in severe inflammatory disorders. Br J Pharmacol. 2009; 158(4):1034-47.

39. Schuh K, Pahl A. Inhibition of the MAP kinase ERK protects from lipopolysaccharide-induced lung injury. Biochem Pharmacol. 2009;77(12): 1827-34.
40. Ferreira AJ, Shenoy V, Qi Y, Fraga-Silva RA, Santos RA, Katovich MJ, Raizada MK. Angiotensin-converting enzyme 2 activation protects against hypertension-induced cardiac fibrosis involving extracellular signal-regulated kinases. Exp Physiol. 2011;96(3):287-94.

41. Imai Y, Kuba K, Neely GG, Yaghubian-Malhami R, Perkmann T, van Loo G, Ermolaeva $M$, Veldhuizen $\mathrm{R}$, Leung $\mathrm{YH}$, Wang $\mathrm{H}$, et al. Identification of oxidative stress and toll-like receptor 4 signaling as a key pathway of acute lung injury. Cell. 2008;133(2):235-49.

42. Kang SR, Han DY, Park KI, Park HS, Cho YB, Lee HJ, Lee WS, Ryu CH, Ha YL, Lee $\mathrm{DH}$, et al. Suppressive Effect on Lipopolysaccharide-Induced Proinflammatory Mediators by Citrus aurantium L. in Macrophage RAW 264.7 Cells via NF-kappaB Signal Pathway. Evidence-based complementary and alternative medicine : eCAM. 2011;2011:1-12.

43. de Martin R, Vanhove B, Cheng Q, Hofer E, Csizmadia V, Winkler H, Bach FH. Cytokine-inducible expression in endothelial cells of an I kappa B alpha-like gene is regulated by NF kappa B. EMBO J. 1993;12(7):2773-9.

44. Baeuerle PA, Baltimore D. NF-kappa B: ten years after. Cell. 1996;87(1):13-20.

45. Kregel $\mathrm{KC}$, Zhang $\mathrm{HJ}$. An integrated view of oxidative stress in aging: basic mechanisms, functional effects, and pathological considerations. Am J Physiol Regul Integr Comp Physiol. 2007;292(1):R18-36.

46. Yoon WJ, Lee NH, Hyun CG. Limonene suppresses lipopolysaccharideinduced production of nitric oxide, prostaglandin E2, and pro-inflammatory cytokines in RAW 264.7 macrophages. Journal of oleo science. 2010;59(8): 415-21.

47. Shih $\mathrm{RH}$, Yang $\mathrm{CM}$. Induction of heme oxygenase-1 attenuates lipopolysaccharideinduced cyclooxygenase-2 expression in mouse brain endothelial cells. J Neuroinflammation. 2010;7:86

48. Chen QY, Wang GG, Li W, Jiang YX, Lu XH, Zhou PP. Heme Oxygenase-1 promotes delayed wound healing in diabetic rats. J Diabetes Res. 2016; 2016:9726503.

49. Stocker R, Yamamoto Y, McDonagh AF, Glazer AN, Ames BN. Bilirubin is an antioxidant of possible physiological importance. Science. 1987;235(4792): 1043-6.

50. Ryter SW, Alam J, Choi AM. Heme oxygenase-1/carbon monoxide: from basic science to therapeutic applications. Physiol Rev. 2006:86(2):583-650.

51. Queiroga CS, Vercelli A, Vieira HL. Carbon monoxide and the CNS: challenges and achievements. Br J Pharmacol. 2015;172(6):1533-45.

52. Ryter SW, Otterbein LE, Morse D, Choi AM. Heme oxygenase/carbon monoxide signaling pathways: regulation and functional significance. Mol Cell Biochem. 2002;234-235(1-2):249-63.

53. Wang XM, Kim HP, Nakahira K, Ryter SW, Choi AM. The heme oxygenase-1/ carbon monoxide pathway suppresses TLR4 signaling by regulating the interaction of TLR4 with caveolin-1. J Immunol. 2009;182(6):3809-18.

54. Chhikara M, Wang S, Kern SJ, Ferreyra GA, Barb JJ, Munson PJ, Danner RL. Carbon monoxide blocks lipopolysaccharide-induced gene expression by interfering with proximal TLR4 to NF-kappaB signal transduction in human monocytes. PLoS One. 2009;4(12):e8139.

55. Chakraborty P, Saraswat G, Kabir SN. Alpha-Dihydroxychalcone-glycoside (alpha-DHC) isolated from the heartwood of Pterocarpus marsupium inhibits LPS induced MAPK activation and up regulates $\mathrm{HO}-1$ expression in murine RAW 264.7 macrophage. Toxicol Appl Pharmacol. 2014;277(1):95-107.

56. Song YS, Park CM. Luteolin and luteolin-7-O-glucoside strengthen antioxidative potential through the modulation of Nrf2/MAPK mediated HO-1 signaling cascade in RAW 264.7 cells. Food Chem Toxicol. 2014;65:70-5.

\section{Publisher's Note}

Springer Nature remains neutral with regard to jurisdictional claims in published maps and institutional affiliations. 